\title{
PELATIHAN TIM CYBER KARANG TARUNA UNTUK PROMOSI PRODUK DAN POTENSI DESA LEGUNG BARAT
}

\author{
Ach. Andiriyanto ${ }^{1}$, Roos Yuliastina ${ }^{2}$ \\ ${ }^{1,2)}$ Dosen Fakultas Ilmu Sosial dan Ilmu Politik Universitas Wiraraja \\ Email: ${ }^{1)}$ enza.resdiana@gmail.com, ${ }^{2)}$ azrilarkan@gmail.com
}

\begin{abstract}
ABSTRAK
Karang Taruna adalah organisasi pemuda yang didirikan dengan tujuan memberikan wadah dalam pemberdayaan pararemaja, misalnya dalam bidang keorganisasian, ekonomi, wisata, olahraga, ketrampilan, advokasi, keagamaan dan kesenian. Berdasarkan tujuan tersebut maka karang taruna merupakan potensi yang perlu diberdayakan sebagai tenaga terampil yang dapat membangun wilayahnya melalui promosi potensi desa dalam perekonomian dan wisata. Mereka mengerti betul mengenai spot-spot wisata yang potensial dan belum diekplorasi oleh orang di luar daerah tersebut. Sebagai tenaga muda yang cenderung lebih mudah menerima pengetahuan dan keterampilan baru maka karang taruna juga potensial diberdayakan dalam mengembangkan dan mempublikasikan potensi yang ada daerahnya. Pengabdian kepada masyarakat berikut akan mengupayakan pemanfaatan multimedia sebagai media promosi/publikasi potensi desa dengan pemberdayaan karang taruna.

Kegiatan ini menggunakan metode: (1) pemberian paparan materi teoritis berupa ceramah diskusi dan tanya jawab; dan (2) dilanjutkan dengan pendampingan (coaching) pengembangan multimedia dan media online sebagai sarana promosi yang tepat oleh tim pengabdi. Dari hasil pengabdian ini karang taruna Legung Barat telah memiliki akun media online sebagao media promosi potensi salah satunya melalui blog cyber karang taruna Desa Legung Barat, dengan alamat https://ckltb.blogspot.com/
\end{abstract}

Kata kunci : Pelatihan, Tim Cyber, Karang Taruna

\section{PENDAHULUAN}

Kondisi topografi di Kabupaten Sumenep dapat dilihat dari ketinggihan lahannya, dan secara umum kabupaten sumenep berada pada ketinggihan 0-500 dan 500-1000 meter diatas pemukaan air laut yang tersebar pada semua daerah yang ada di Sumenep, sehingga berdasarkan ketinggihannya ini Kabupaten Sumenep dapat di kategorikan menjadi 2 bagian yaitu:

a. Wilayah dengan ketinggian 0-500 meter dpl seluas $208.697,40 \mathrm{Ha}$ atau mencapai luasan sekitar 99,72\% dari seluruh luaswilayah Kabupaten Sumenep

b. Wilayah yang memiliki ketinggian 5001000 meter dpl mencapai luasan 578,42 Ha atau sekitar $0,28 \%$ dari seluruh luaswilayah Kabupaten Sumenep. Selain ketinggian, kondisi topografi juga dapat dilihat dari kemiringan lahan luas wilayah Kabupaten Sumenep dengan luas sekitar 2.093,458 $\mathrm{Km}^{2}$, memiliki tingkat kemiringan lahan yang bervariasi

c. Secara goegrafis Kabupaten Sumenep yang terletak diujung timur Pulau Madura terbagi dalam 2 (dua) wilayah yaitu Wilayah Daratan dan Kepulauan. Wilayah Daratan dengan luas 1.146,927 Km2 $(54,79 \%)$ terbagai atas 18 Kecamatan, Sedangkan Wilayah kepulauan dengan luas 946,531 Km2 (45,21\%) terbagi atas 9 Kecamatan.Sumenep adalah daerah yang memiliki banyak potensi dalam semua bidang seperti dalam bidang pertanian, peternakan, perikanan, industri makanan, industri kerajinan (batik dan keris) dan 
aneka potensi wisata yang sangat potensial antara lain: wisata sejarah ( keraton Sumenep), wisata seni dan budaya (karapan sapi, musik tong-tong, dll), wisata religi ( makam-makam raja-raja dan ulama besar) dan wisata alam ( berbagai pantai yang memikili pasir putih yang indah dan taman laut yang eksotis). Diantara sekian banyak daerah wisata yang berada di Kabupaten Sumenep, terdapat salah satu daerah yang bernama kecamatan batangbatang yang memiliki potensi yang melimpa dari segala segi, daerah ini menawarkan objek wisata yang menarik, memiliki usaha produksi makanan dan kerajinan. Potensi yang dimiliki desa ini masih belum banyak orang yang tahu, hal ini sangat disayangkan, hal ini dikarenakan kurangnya publikasi dan promosi portensi desa yang mereka miliki, padahal sebenarnya masih banyak potensi desa yang bisadijadikan tujuan wisata dan usaha perdagangan yang menarik. Selain potensi tersebut, para pemuda di Desa Legung Barat inijuga memiliki antusias tinggi dalam usaha memperkenalkan desanya ke masyarakat luas, salah satunya adalah para pemuda karang taruna desa Legunng Barat.

Karang Taruna adalah organisasi pemuda yang didirikan dengan tujuan memberikan wadah dalam pemberdayaan para remaja, misalnya dalam bidang keorganisasian, ekonomi, wisata, olahraga, ketrampilan, advokasi, keagamaan dan kesenian (Peraturan Menteri Sosial RepublikIndonesia: 2010).

Berdasarkan tujuan tersebut maka karang taruna merupakan potensi yang perlu diberdayakan sebagai tenaga terampil yang dapat membangun wilayahnya melalui promosi potensi desa dalam perekonomian dan wisata. Mereka mengerti betul mengenai spot-spot wisata yang potensial dan belum diekplorasi oleh orang di luar daerah tersebut. Sebagai tenaga muda yang cenderung lebih mudah menerima pengetahuan dan keterampilan baru maka karang taruna juga potensial diberdayakan dalam mengembangkan dan mempublikasikan potensi yang ada daerahnya. Pada era ini hal yang paling memungkinkan dan mudah dilakukan oleh para pemuda dalam mempublikasikan potensi daerahnya dalah melalui media online seperti media sosial.

Menindaklanjuti adanya permasalahan terkait belum tereksplorasinya potensi desa yang dapat memberikan dampak peningkatan ekonomi dan kesejahteraan masyarakat di desa Legung Barat, melalui pemberdayaan karang taruna yang ada dapat membantu mempromosikan potensi desa masing-masing. Mengingat perkembangan daerah wisata dengan banyaknya pengunjung yang datang akan berbanding lurus dengan perekonomian pada desa tersebut, sehingga dibutuhkan publikasi yang bagus melalui pemanfaatan media online. Pengabdian kepada masyarakat berikut akan mengupayakan pemanfaatan multimedia sebagai media promosi/publikasi potensi desa dengan pemberdayaan karang taruna.

Oleh karena itu, Tim LPPM Universitas Wiraraja Sumenep dirasa sangat perlu mengadakan pelatihan dan pendampingan pengembangan potensi desa melalui media online sebagai sarana publikasi dan promosi potensi desa kepada para pemuda karang taruna masyarakat setempat dalam rangka meningkatkan kreatifitas dan softskill. Dengan harapan dengan adanya pelatihan tersebut dapat memotivasi semangat dan kepedulian pemuda karang taruna dalam pengembangan desa mereka, yang pada akhirnya diharapkan memberikan banyak perubahan positif secara sosial dan ekonomi 
terhadap masyarakat Legung barat kecamatan Batang-Batang.

Berdasarkan observasi lokasi dan analisis situasi, makadapat diidentifikasi beberapa permasalahan yang dihadapi oleh Mitra yaitu yang pertama masih sedikit nya wisatawan yang berkunjung di Kabupaten Sumenep hal ini disebabkan kurangnya publikasi desa. Kedua, Para pemuda desa hampir 90\% merupakan pengguna alat komunikasi Handphone tetapi masih menggunakannya untuk kepentingan individu saja, jadi masih kurangnya pemberdayaan karang taruna dan pemanfaatan media online dalam mempromosikan/publikasi potensi yang ada di desanya. Dari beberapa paparan sebelumnya diketahui bahwa peran multimedia dalam promosi pada berbagai jenis media sangat signifikan (http://tekno.liputan6.com/read/orangindonesia-paling-sering-akses- media-sosial).

Pemberdayaan karang taruna dinilai mampu menjembatani ketimpangan minimnya media promosi. Potensi SDM muda yang handal dan mengerti betul kekhasan daerah dan potensi di Sumenep terutama desa Legung Barat menjadi nilai yang penting dalam pengembangan konten promosi potensi desa. Telah diketahui dari observasi awal dan wawancara dengan pemuda di Legung barat menunjukkan bahwa penguasaan pemahaman dan keterampilan mengenai multimedia karang taruna belum optimal.

Berikut ini upaya-upaya untuk peningkatan penguasaan pemahaman dan keterampilan mengenai media online karang taruna yang dirumuskan tim pengabdi: (1) sosialisasi pertama tentang pemberdayaan karang taruna sebagai pelopor promosi potensi desa; (2) pelatihan pengenalan media online; (3) penugasan analisa potensi desa; (4) pendampingan pengembangan media online oleh Tim; dan (5) Workshop optimalisasi media online sebagai sarana promosi.

\section{METODE}

Agar pelaksanaan program ini dapat menghasilkan tujuan yang diharapkan, maka kegiatan ini memerlukan metod eyang tepat. Secara umum kegiatan ini berupa: (1) pemberian paparan materi teoritis berupa ceramah diskusi dan tanya jawab; dan (2) dilanjutkan dengan pendampingan (coaching) pengembangan multimedia dan media online sebagai sarana promosi yang tepat oleh tim pengabdi.

Melihat dari permasalahan yang dihadapi mitra, maka untuk melaksanakan kegiatan pengabdian masyarakat tim melakukan metode pendekatan meliputi;

a. Observasi

Pendekatan ini tim melakukan observasi dengan secara langsung datang ke lokasi di Desa Legung Barat Kecamatan BatangBatang, melakukan observasi kegiatan pemuda desanya.

b. Wawancara

Pengabdi melakukan wawancara kepada beberapa pemuda dan stake holder di desa tersebut mengenai kondisi Masyarakat dan potendi desa. Terkait permasalahan, hambatan atau kendaa masyarakat setempat dalam pengembangan potensi desa yang dimiliki..

c. Pendataan

Tim melakukan pendataan tentang jumlah pemuda yang aktiv dalam kegiatan desa, pendataan potensi yang dimiliki desa baik dalam potensi wisata, hasil produksi makanan dan kerajinan.

d. Menyiapkan Peralatan

Sebelum melakukan pelatihan tim merancang dan menyiapkan materi berupa modul sederhana untuk dijadikan pedoman dalam pelatihan. 
e. Pelatihan

Dengan mendatangkan nara sumber yang kompeten dalam bidang multimedia dan media online dan mengundang pihak-pihak terkait seperti para aparat desa, pemuda.

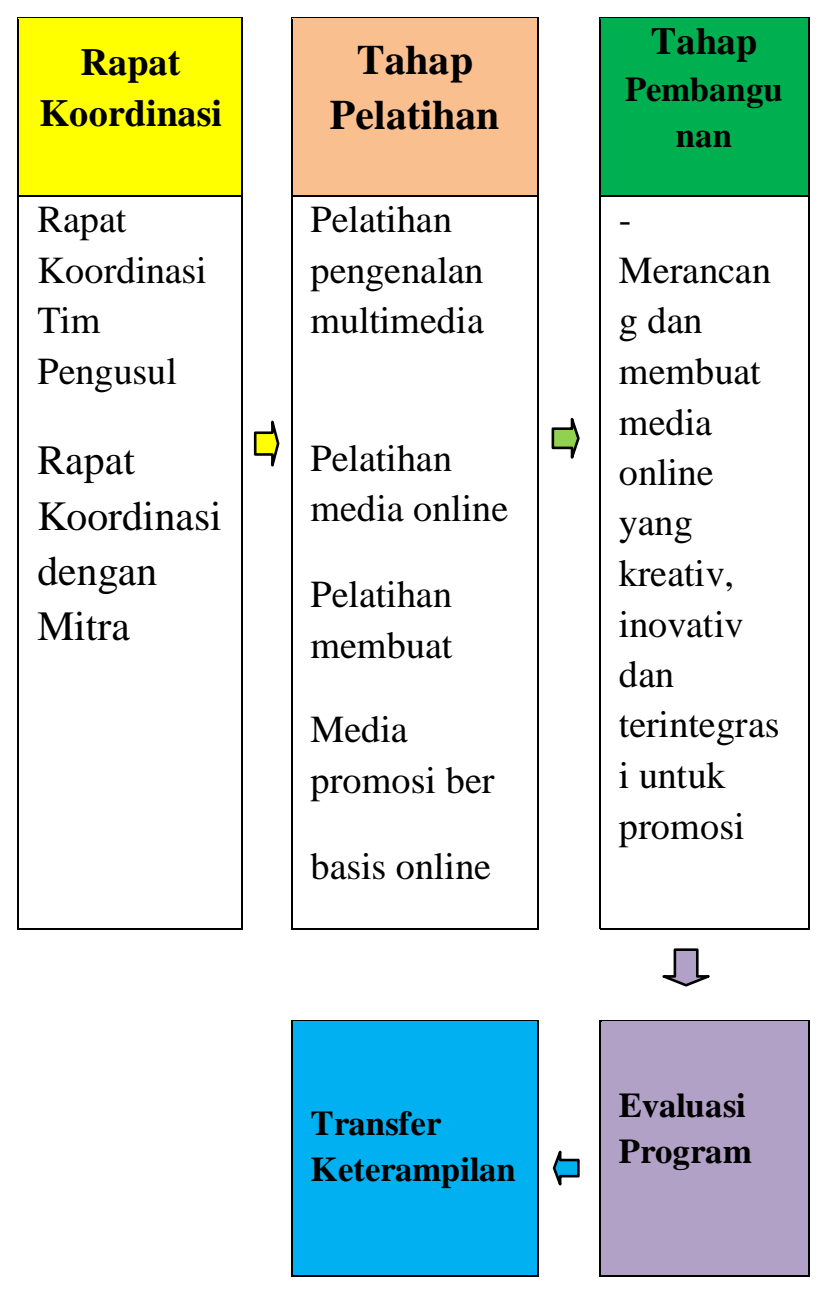

\section{HASIL DAN PEMBAHASAN}

\section{Terbentuknya Tim Cyber}

Kegiatan pengabdian pada masyarakat ini mendapatkan sambutan positif dari pihak karang taruna di Desa Legung Barat,terutama karena program ini sesuai dengan kebutuhan desa yang memiliki banyak potensi namun belum banyak masyarakat yang mengetahuinya. Bentuk sambutan positif tersebut antara lain terlihat dari partisipasi aktif, baik dari pihak karang taruna, khususnya kepala desa yang selalu setia mendampingi para peserta pelatihan kepala desa, dikarenkan inovasi ini pun tidak terlalu membutuhkan fasilitas yang cukup banyak namun hanya pemanfaatan ponsel (android) sebagai media untuk mempublikasikan serta kreatifitas setiap individu dalam membuat publikasi desa.

Menurut peserta, pemanfaatan media blog berbasis android sangat mudah untuk digunakan. Dikarenakan memiliki mayoritas anggota karang taruna memiliki tingkat pendidikan Sarjana disamping itu menu yang tersedia sangat sederhana dan pengguna dapat menambahkan sendiri gambar maupun tulisan. Peserta pelatihan menganggap aplikasi ini sangat praktis dan efektif, walaupun kendala yang terdapat pada pelatihan ini adalah dari segi kreatifitas dalam membuat informasi yang menarik.

Motivasidari kepala desa kepada karang taruna sangat besar hal ini ditandai dengan dibentuknya tim cyber karang taruna dan memberikan jaminan kepada karang taruna jika ke depan mereka aktif dalam mempromosikan desa dan produk desa maka ke depan mereka akan diberikan tanggung jawab untuk ikut mengelola BUMDES yang selama ini belum ada kegiatan sama sekali. serta pemenuhan fasilitas yang dibutuhkan oleh Tim Cyber Karang Taruna.

Antusiasme karang taruna juga tercermin dari peningkatan kemampuan mereka dalam pemanfaatan blogspot dan pemakaian aplikasi WEB berbasis android yang didapat setelah mengikuti pelatihan serta konten yang diinformasikan lebih menarik, pada tahap awal para peserta mencoba membuat informasi yang menarik tentang salah satu potensi wisata desa yaitu pantai air tawar.

Penerapan dari pelatihan pengemasan atau packaging itu sendiri mulai dipraktekkan oleh para tim cyber dengan merangkul beberapa unit usaha di desa tersebut, beberapa 
Unit usaha kecil di desa tersebut juga sudah terbantukan oleh tim cyber karang taruna dengan memberikan sentuhan Packaging pada produk yang dimilikinya yang kemudian di nantinya publikasikan di blog cyber karang taruna desa Legung Barat, dengan alamat https://ckltb.blogspot.com/ (Trial-Blogwisata)

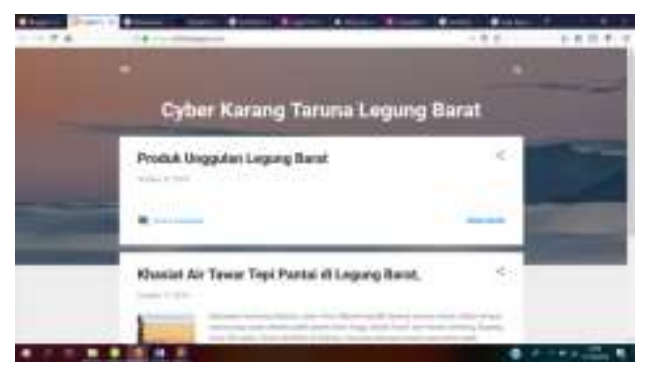

Gambar 1. Blog pariwisata miliki kaarang taruna Legung Barat

Dari Pelatihan ini dapat diketahui bahwa peserta pelatihan mendapatkan tambahan wawasan tentang penggunaan internet khususnya berbasis android sebagai media untuk publikasi potensi desa. Penerapan teknologi tidak memandang usia, namun sejauh mana individu tersebut membuka diri pada perkembangan teknologi itu sendiri dan mengembangkannya sesuai dengan kebutuhan. Sekarang tergantung dari keperluan individu dan tujuan yang ingin dicapai.

Setelah kegiatan selesai dilaksanakan diharapkan pihak desa melakukan upayaupaya tindak lanjut untuk untuk pengembangan potensi desa. Hasil yang didapat selama pelatihan diharapkan mampu menjadi pemacu semangat bagi pihak desa maupun tim cyber karang taruna itu sendiri untuk selalu meningkatkan kemampuan mereka dalampengembangan desa dan ikut berpartisipasi dalam menuangkan ide pada segi pengembangan desa.

\section{Potensi Unggulan Legung Barat}

Selain melakukan pelatihan dan pendampingan pembuatan media promosi online, pengabdian ini juga membantu para anggota tim karang taruna Legung Barat dalam menemukan dan mempromosikan keunggulan produk khas desa Legung Barat, pemetaan produk unggulan dilakukan dalam rangka menunjang produk desa yang akan dipublikasikan pada media sosial milik tim cyber karang taruna. Adapun langkah yang dilakukan adalah:

a. Mengumpulkan data terlebih dahulu, melalui kegiatan FGD (focus group dicussion) yang melibatkan ketua beserta anggota tim karang taruna Legagung barat, Wakil kepala desa Legung Barat, dan tiga perwakilan tokoh pemuda Legung Barat.

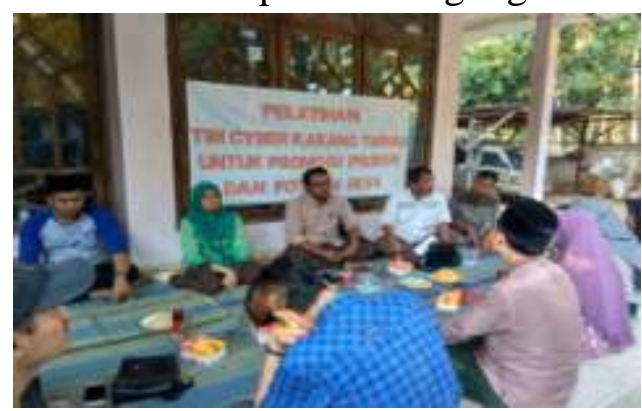

Gambar 2. Kegiatan diskusi antara tim pengabdian dengan tim cyber karang taruna

b. Berdasarkan hasil diskusi tersebut, tim cyber karang taruna Lengung Barat memutuskan untuk saat ini dua produk unggulan yang akan dijadikan sebagai bahan promosi khas desa Legung barat, yaitu: (1) Potensi Alam pantai air tawar, (2) Produk UMKM krupuk Gambir khas desa Legung Barat. Krupuk Gambir yang akan dipromosikan melalui media online oleh tim cyber karang taruna, adalah produk UMKM yang telah melalui tahapan pelatihan kemasan dan branding logo produk yang dilakukan oleh tim KKNPPM Unija tahun 2019.

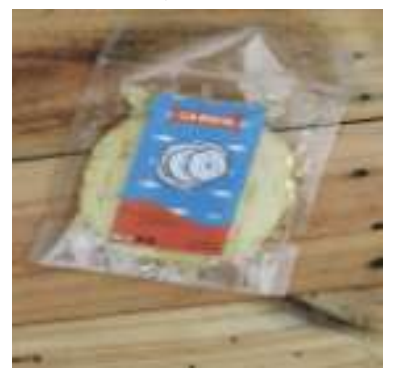

Gambar 3. Produk UMKM Krupuk Gambir yang akan dipromosikan 


\section{KESIMPULAN}

Kegiatan pelatihan tim cyber ini menyasar kelompok anak muda setempat karena $90 \%$ pemuda pemudi disana memiliki alat komunikasi Handphone tetapi masih menggunakannya untuk kepentingan individu saja, oleh karena itu ingin diarahkan juga pada kegiatan positif seperti menjadi tim cyber promosi potensi desa menggunakan gatged mereka. Adapun tahapan kegiatan pengabdian ini diantaranya, 1) pengenalan media online ; (2) analisa potensi desa; (3) pengembangan media online oleh Tim; (4) pelatihan optimalisasi media online sebagai sarana promosi. Dari hasil pengabdian ini karang taruna Legung Barat telah memiliki akun media online sebagao media promosi potensi salah satunya melalui blog cyber karang taruna desa Legung Barat, dengan alamat https://ckltb.blogspot.com/ (Trial-Blogwisata)

\section{DAFTAR PUSTAKA}

Agustinus, Mario Damar. 2015. Orang Indonesia Paling Sering Akses Media Sosial.

Arevin, Ayat Taufik. 2007. Perencanaan Dan Rancangan Program Penyuluhan Sadar Wisata Bagi Pengelola Usaha Rumah Makan Di Kota Bogor. Panorama Nusantara edisi III/JuliDesember.

Dokumen elektronik diambil dari http://tekno.liputan6.com/read/23749 40/orang-indonesia-paling-seringakses-media-sosialpada22Februari 2016

Peraturan Menteri Sosial RepublikIndonesia, 2010. Pedoman Dasar Karang Taruna.

Vaughan, T. 2011. Multimedia: making it work (8thed.). NewYork: McGrawHill. 